\title{
液圧を穿刺に用いる注射器の開発に関する基礎研究
}

\section{Basic Study for Development of New Insertion Device Using Hydraulic Pressure}

\author{
今津篤志 (正会員) $\mathrm{a}^{*}$, 苗村 潔 $\mathrm{b}$, 齋藤英也 $\mathrm{c}$, 田中 孝 $\mathrm{c}$ \\ $\mathrm{a}$ 東京工科大学コンピュータサイエンス学部 \\ $\mathrm{b}$ 東京工科大学応用生物学部 \\ c株式会社ユニシス
}

\author{
Atsushi Imadu ${ }^{a}$, Kiyoshi Naemura ${ }^{\mathrm{b}}$, Hideya Saito $^{\mathrm{c}}$, Takashi Tanaka $^{\mathrm{c}}$ \\ ${ }^{a}$ School of Computer Science, Tokyo University of Technology \\ ${ }^{\mathrm{b}}$ School of Bioscience and Biotechnology, Tokyo University of Technology \\ ${ }^{\mathrm{c}}$ Unisis Corporation
}

\begin{abstract}
This paper describes the development of a new insertion device that uses hydraulic pressure to position the needle of the device. This device simplifies insertion operations into cavities such as insertion for lumber epidural anesthesia; damage that can be caused to the tissue behind the cavities by overrun insertion is also avoided. When a anesthesiologist pushes the plunger, the needle moves forward to insert and then stops automatically when its tip reaches into the cavity; the automatic stopping is caused by the opening of a pressure chamber at the tip of the needle that limits the hydro pressure to the pressure outside the tip of the needle. Insertion experiments to simulators and porcine tissue were performed to verify the function of the proposed device, that is, needle movement and automatic stopping at cavities. These experiments were found to validate the basic formulae of the cross-sectional areas of the cylinders to control the insertion force and plunger force.
\end{abstract}

\section{Key words}

Insertion, Hydraulic Pressure, Epidural Space.

\section{1. はじめに}

注射は体内の腔や組織に薬液を投入することを目 的とし, 注射針の穿刺においては注射針の先端を目的 の腔や組織に到達させ, 停止させるように穿刺深度を 調節することが重要である. 例えば硬膜外麻酔用の穿 刺においては, 注射針先端が棘上靭帯, 棘間勒帯, 黄

*現 $\cdot$ 大阪市立大学

于558-8585 大阪市住吉区杉本 3-3-138

imadu@mech.eng.osaka-cu.ac.jp

受付 2009 年 11 月 9 日; 採択 2010 年 4 月 27 日
色勒帯を貫通して硬膜外腔に達し, 針深さ方向に数 $\mathrm{mm}$ しかない硬膜外腔の空間で停止する必要があり, その奥の硬膜を針先で損傷してしまうと頭痛などの 後遺症を引きおこしてしまうことが知られている ${ }^{1)}$.

現在は, 硬膜外腔の内圧が他の組織での内圧よりも 低いことを利用し，針につけたシリンジを押したとき に押し返されなくなることを確認する抵抗消失法や, 針の根元につけた液体が吸い込まれることを確認す る懸滴法などによって逐次確認を行ないながら, 術者 
が穿刺反力の感覚を頼りに針を進めていく手技 ${ }^{2)}$ が 一般的である.この手技は術者の経験と熟練によると ころが大きいため, 手技習得の補助を目的とする抵抗 消失の定量化の研究 ${ }^{3)}$ や穿刺状態をセンサでモニタし て拡大して術者に伝える装置の開発 ${ }^{4) 5) な と ゙ か ゙ な さ れ ~}$ ている。

本研究では，抵抗消失法や懸滴法において硬膜外腔 とそこにいたる組織が内圧によって区別されている ことに着目し，液圧を利用して針を進ませることで機 構的に針を空隙まで穿刺して止めることができる注 射器の原理を考案した。本注射器を用いることで，手 技を確実にするとともに簡素化して手技習得期間を 短縮することが期待される.

本報告では，その原理と基本特性，設計法を明らか にし, 穿刺練習用シミュレータおよびブタ骨付きロー ス肉への穿刺実験による確認結果を示す.

\section{2. 方法}

\section{1 提案注射器の穿刺動作原理}

Fig. 1 に本論文で提案する注射器の構造を説明する 断面図を示す．シリンダ内を前後に移動する移動子 (Slider)があり，注射針は移動子に固定され一体となっ てシリンダに沿って移動する. 以降このシリンダを移 動子側シリンダ(Cylinder for Slider) と呼ぶこととする. 移動子側シリンダは，プランジャ側シリンダ(Cylinder for Plunger) と気密性を保って結合されており，移動子， 移動子側シリンダ, プランジャ側シリンダとプランジ ヤによって囲まれる液室が構成されている.

ここで液室は，移動子と針の内部を通じて針先端の 穴で開放されている。.また液室には薬液や生理食塩水 などの非圧縮性の流体を充填する.

Fig. 2 に，本機構のパラメータや作用する力，動作 速度などを表わした図を示す。ここで $S_{m}$ は移動子側

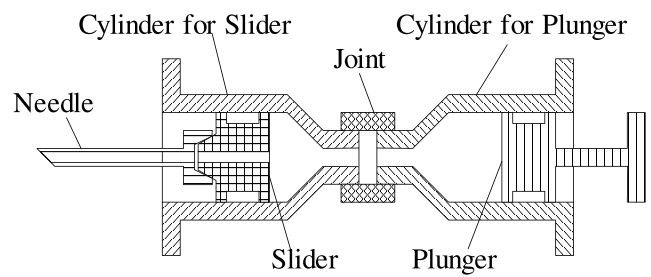

Fig. 1 Cross Section Drawing of Proposed Device.

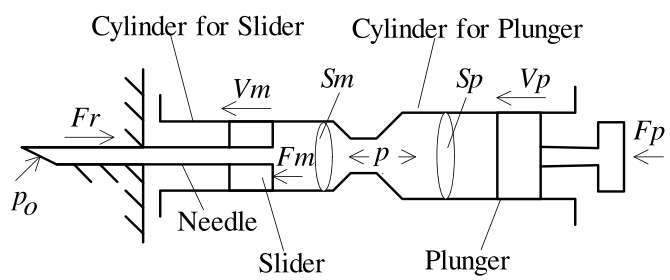

Fig. 2 Mechanical Variables.

シリンダの断面積を, $S_{p}$ はプランジャ側シリンダの 断面積を表わす。

プランジャが押されることによって液室内に満た された液体の液圧 $p$ が高まると, 移動子と注射針は式 (1)の力 $F_{m}$ で穿刺方向に押される.

$$
F_{m}=p \times S_{m}
$$

ここで液室は針先端まで通じた穴によって針先端 に開放されているため, 液圧 $p$ は基本的に針先端外部 の圧力 $p_{o}$ 以上には大きくならない. したがって, 移 動子の移動により針を穿刺するための力すなわち穿 刺反力を $F_{r}$ として,$F_{r}<S_{m} \times p_{o}$ のときは針が前進し， $F_{r}>S_{m} \times p_{o}$ のときは液体が針先端から放出される.

目標とする硬膜外腔では内圧が低く途中の筋組織 などでは内圧が高いことから, 硬膜外腔の内圧を $p_{g}$, 硬膜外腔以外の筋組織などの最小の内圧を $p_{m}$ として, 式(2)が成り立つように $S_{m}$ を設計することで，プラン ジャを押したときに，針先が途中の筋肉や勒帯にある 間は針が前進し，針先が硬膜外腔に達すると針が進ま なくなる機能が機構的に実現できる. なお, 最初に針 先を皮膚に穿刺する動作は，人間が針を抑えるか，移 動子をストロークエンドにあてて行なう。

$$
S_{m} \times p_{g}<F_{r}<S_{m} \times p_{m}
$$

より㛜密には, 黄色靭帯を突き抜けるまでに必要な最 大の穿刺反力 $F_{r \max }$ と黄色靭帯を突き抜けた直後にさ らに針を進めるために必要な $F_{\text {rrestart }}$ を用いて $S_{m}$ が 式(3)の範囲にあれば良い.ここで $F_{r \text { max }}$ と $F_{\text {r restart }}$ には， 移動子とシリンダ間のガスケットの摺動摩擦が含ま れている。

$$
\frac{F_{r \max }}{p_{m}}<S_{m}<\frac{F_{\text {rrestart }}}{p_{g}}
$$

また，プランジャ移動部分のシリンダ断面積を $S_{p}$, プランジャとシリンダ間の摺動摩擦を $F_{r p l}$ とすると, プランジャ操作力 $F_{p}$ は式(4)であらわすことができる. 針が進み始める境界值では $F_{m}=F_{r}$ が成り立っている 
ことおよび式(1) と式(4)より $p$ を消去すると,$F_{p}$ と $F_{r}$ との関係式 $(5)$ が求められる.

$$
\begin{aligned}
& F_{p}=p \times S_{p}+F_{r p l} \\
& F_{p}=F_{r} \times \frac{S_{p}}{S_{m}}+F_{r p l}
\end{aligned}
$$

式(5)において, 摺動摩擦 $F_{r p l}$ が穿刺反力 $F_{r}$ に比べて 相対的に小さいとすると, プランジャ操作力は穿刺反 力に比例する. したがって, プランジャを人間が押す と, 通常の針を持って行なう穿刺時の穿刺反力と相似 な波形の反力を感じることになる。式(5)より， $S_{m}>S_{p}$ のときは, 通常の針を持って行なう穿刺より も小さな力で針を進めることが可能である。一方, $S_{m}<S_{p}$ のときは, 通常の針を持って行なう穿刺より も大きな力が必要であるが, 黄色勒帯を突き破ったと きの反力の変化も大きく感じ取ることが可能である.

また移動子が移動するときのプランジャの速度 $V_{p}$ と移動子の速度 $V_{m}$ の関係は式(6)で表わすことができ る.

$$
V_{m} / V_{p}=S_{p} / S_{m}
$$

式(5), (6)より人間がプランジャを押したときに受け る感覚, すなわち穿刺に要する力や受ける反力, プラ ンジャを押す速度と移動子の移動速度の関係を $S_{m}$ と $S_{p}$ の設計によって調節することが可能である.

\section{2 提案注射器の設計}

Table 1 に, 断面設計のために取得した筋肉組織の 内圧と穿刺反力の予備データと, そこから求められる 設計值を示す。まず，ブタの背中の筋肉部分に筋肉注 射を行なったときの圧力 $p_{m}$ を測定した.つまり，こ の圧力以上の圧力が作用すると液室内の液体が筋肉

Table 1 Pressure and Reaction Force of Porcine Tissue.

\begin{tabular}{|l|l|}
\hline & Value \\
\hline Pressure in Muscle $p_{m}$ & $43 \mathrm{kPa}$ \\
\hline Reaction Force $F_{r}$ & $3 \mathrm{~N}$ \\
\hline $\begin{array}{l}\text { Minimum Cross Sectional Area of Cyliner } \\
\text { for Slider Sm }\end{array}$ & $69.8 \mathrm{~mm}^{2}$ \\
\hline $\begin{array}{l}\text { Minimum Diameter of } \\
\text { Cylinder for Slider } d m\end{array}$ & $8.3 \mathrm{~mm}$ \\
\hline
\end{tabular}

内に流出する. 次に, 以降で使用する $18 \mathrm{G}$ の硬膜外麻 酔針をブタの背中の筋肉に穿刺したときの穿刺反力 $F_{r}$ を測定した. これらの值から式(1)および $F_{m}=F_{r}$ を 用いて断面積を算出すると, 筋肉内に液体が流出せず に針が穿刺される移動子側シリンダの断面積 $S_{m}$ の最 低值を求めることができる.さらにこの断面積を持つ 円の直径が円筒形シリンダの最小の内径として求め られる.

得られた最小断面積を参考に, 本報告では市販のシ リンジをシリンダとして利用した。 ここで移動子側シ リンジは, 通常のプランジャを取り去り, Fig. 1 に示 すようにプランジャが入っていた側を前方として, 移 動子を挿入した.

移動子側, プランジャ側シリンジとして, LOR (Loss of Resistance) シリンジと汎用の樹脂製シリンジを使 用した. LOR シリンジは抵抗消失法で押し返しを敏 感に感じるためにプランジャとガスケットの摺動抵 抗を通常のシリンジに比べて小さくしたシリンジで あり, 摺動抵抗が小さいことが望ましい本デバイスに は適している.しかし LOR シリンジは内径のバリエ ーションが限られているため, 以降では LOR シリン ジを中心に, 樹脂製シリンジも使用して実験を行なった。

使用したシリンジを実測した内径と内径から計算 した断面積と断面積比を Table 2 に示す．ここで断面 積比は LOR シリンジを基準とした断面積の比である.

Fig. 3 亿設計・製作した移動子の外観および断面図 を示寸. 移動子は, 移動子本体部品（Fig.3 (a)の白い 部分）と 2 つガスケット, ルアーコネクタから構成 され，対応する移動子側シリンジごとに計 4 種類を製 作した.

移動子にはシリンダとの気密性を保ちながら滑ら かに移動することが求められるため, 市販シリンジの プランジャのガスケットを流用し, ガスケットの中央

Table 2 Syringe Parameters.

\begin{tabular}{|c|c|c|l|}
\hline $\begin{array}{c}\text { Inside } \\
\text { Diameter }\end{array}$ & $\begin{array}{c}\text { Cross } \\
\text { Sectional } \\
\text { Area }\end{array}$ & $\begin{array}{c}\text { Cross } \\
\text { Sectional } \\
\text { Area Ratio }\end{array}$ & $\begin{array}{c}\text { Volume of } \\
\text { Syringe }\end{array}$ \\
\hline $13.3 \mathrm{~mm}$ & $138.9 \mathrm{~mm}^{2}$ & 0.73 & $5 \mathrm{~mL}$ \\
\hline $15.5 \mathrm{~mm}$ & $188.7 \mathrm{~mm}^{2}$ & 1.00 & $10 \mathrm{~mL}(\mathrm{LOR})$ \\
\hline $20.3 \mathrm{~mm}$ & $323.7 \mathrm{~mm}^{2}$ & 1.71 & $25 \mathrm{~mL}$ \\
\hline $23.4 \mathrm{~mm}$ & $430.0 \mathrm{~mm}^{2}$ & 2.28 & $30 \mathrm{~mL}$ \\
\hline
\end{tabular}




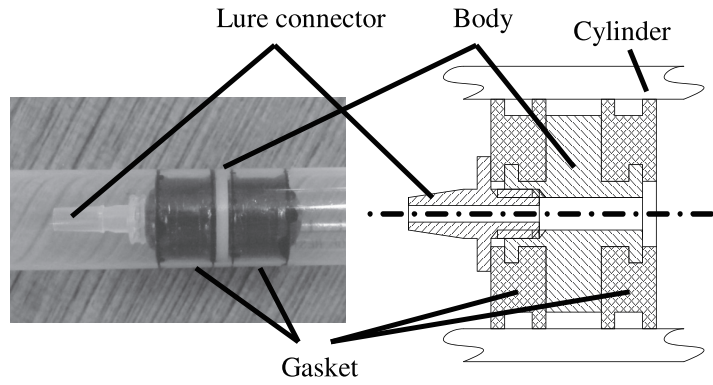

(a) Apparatus

(b) Cross Sectional Drawing

Fig. 3 Slider Parts

に貫通穴を開けて用いた．針にかかるモーメントを支 えるために, 移動子本体の両端にガスケットを設置し た

また移動子本体部品の左側のめねじ部に, 隔壁固定 用のおねじ付ルアーコネクタをねじ込み，ガスケット と密着させている.このルアーコネクタに従来用いら れている針を接続することが可能である. 以下の実験 では $18 \mathrm{G}$ の硬膜外麻酔用 Tuohy 針（ユニシス）を用 いた。

\section{3 シミュレータに対する穿刺実験}

まず, 動作原理の実現と設計式の妥当性を確認する ため, シミュレータを穿刺対象とし，移動子側シリン ジとプランジャ側シリンジを取り換えて断面積 $S_{m}$, $S_{p}$ の組み合わせを変えながら実験を行なった。使用 したシミュレータは硬膜外穿刺パッド（Epidural Puncture Block M43B，京都科学）である.

Fig. 4 に穿刺シミュレータへの穿刺実験に用いたシ ステムの構成図を示す. 移動子側シリンジとプランジ ヤ側シリンジを三方活栓で接続し，三方活栓の残りの 一端に圧力センサを接続して液室内の圧力 $p$ を測定

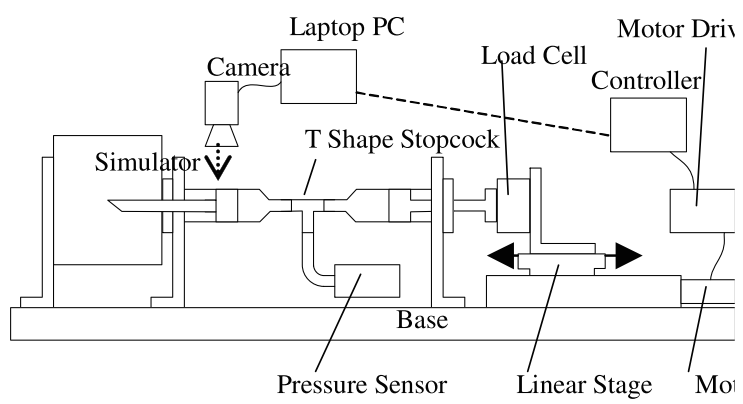

Fig. 4 Experimental Setup for Insertion to Simulator
した、また，サーボモータとボールねじによる移動ス テージを用いて, プランジャを停止状態から, 一定速 度 $V_{p}$ の速度指令で測定時間終了まで押し続けた。実 際のステージ速度はモータの制御により開始から $20 \mathrm{~ms}$ 以内で指令の速度と一致していた。プランジャ 速度 $V_{p}$ は $10 \mathrm{~mm} / \mathrm{s}$ と $5 \mathrm{~mm} / \mathrm{s}$ で行なった。 またプラン ジャとステージの間にロードセルを設置してプラン ジャ操作力 $F_{p}$ を測定した.

移動子はシリンジ外筒の内部で移動しているため, その位置を直接測定することはできず，シリンジ外筒 越しに移動子を画像に取り, 移動子画像のテンプレー トマッチング解析を用いて移動子の位置 $x_{m}$ を算出し た.さらに， $x_{m}$ の時間差分によって $V_{m}$ を算出した.

なお，作動流体としては生理食塩水が用いられるこ とが多いと考えられるが, 生理食塩水と純水の粘度の 違いが $2 \%$ 程度である ${ }^{6)}$ など物理的な特性はあまり違わな いため, 以降の実験では利便性の良い水道水を用いた。

\section{4 ブタ骨付きロース肉に対する穿刺実験}

次に, 食用のブタ骨付きロース肉の固まりを用いて 穿刺実験を行なった。 より人間に近い筋肉, 靭帯組織 への穿刺を行なうことができることに加えて，ブタ骨 付き口ース肉は正中線に沿って縦方向に半分に切断 されているため, 硬膜外腔に貫通して出てくる針先の 様子を目視確認することができる.

Fig. 5 にブタ骨付きロース肉への穿刺実験に用いた システムの構成図を示す.プランジャ側シリンダおよ び移動ステージ, 圧力 $p$ およびプランジャ操作力 $F_{p}$, 移動子位置 $x_{m}$, 速度 $V_{m}$ の測定システムは Fig. 4 と同 様である.ここでプランジャ速度 $V_{p}$ は $5 \mathrm{~mm} / \mathrm{s}$ とした。

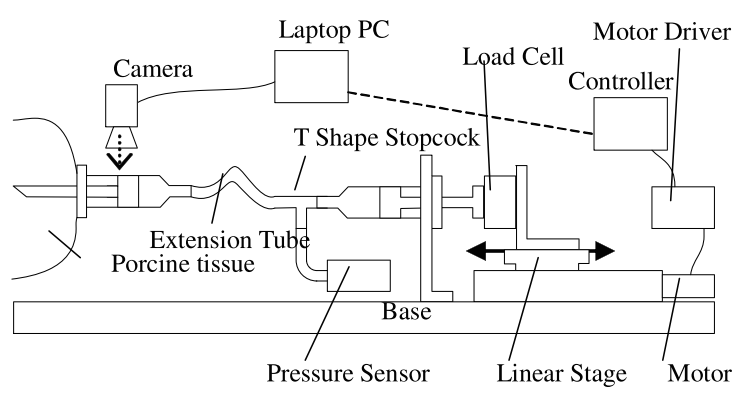

Fig. 5 Experimental Setup for Insertion to Porcine Tissue. 
また移動子側シリンジと三方活栓の間にエクステ ンションチューブ $1.5 \mathrm{~m}$ を挟んでステージからの距離 を延長し, 移動子側シリンジを人間が対象に押しつけ て実験を行なった。

\section{3. 結果}

\section{1 シミュレータに対する穿刺結果}

Fig. 6 に穿刺シミュレータに対する穿刺実験を行な ったときのシリンダ内圧力 $p$, プランジャ操作力 $F_{p}$ と移動子変位 $x_{m}$ の時間変化の一例を示寸. ここで, 移動子側およびプランジャ側のシリンジは $\phi 15.5$ の LOR シリンジであり, プランジャ速度 $V_{p}$ は $10 \mathrm{~mm} / \mathrm{s}$ である.

Fig. 6 上図において, データ開始と同時にプランジ ヤが動き始めて圧力が高まると移動子が動き始め, 同 時に圧力 $p$, プランジャ操作力 $F_{p}$ の最初のピーク (1st Peak)が観測された。そして針先端が硬膜外腔部分に 達したときを 2 つのピーク (2nd Peak)として圧力, プランジャ操作力が低下し, 移動子の動きが停止する ことが確認できた. またプランジャ操作力 $F_{p}$ は, 式 (1)のとおりほぼ圧力に比例していることが確認でき た.

次に, 移動子側シリンジとプランジャ側シリンジを 取り換えて断面積の組み合わせを変えた時の圧力 $p$ の最大值, プランジャ操作力 $F_{p}$ の最大值および穿刺 中の移動子の平均速度 $V_{m}$ を Fig. 7 に示寸. それぞれ
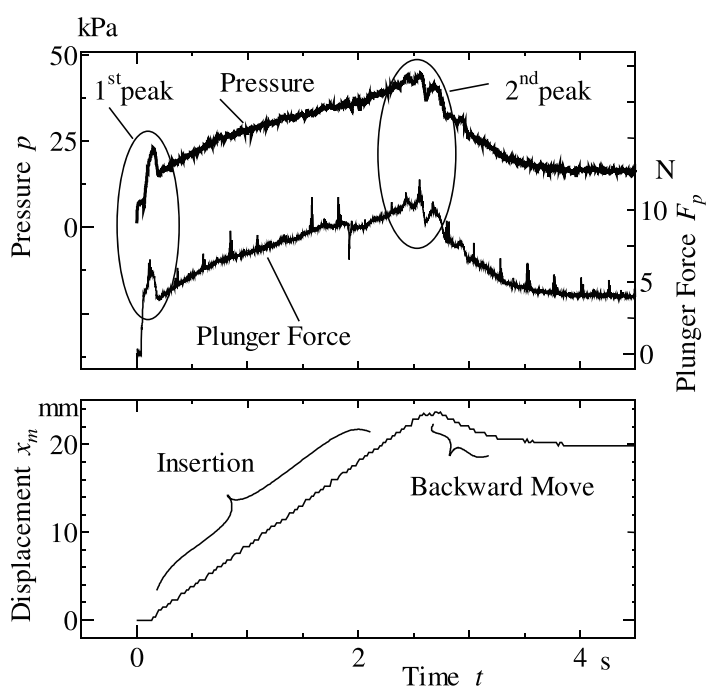

Fig. 6 Time History of Pressure, Plunger Force and Displacement on Insertion to Simulator.
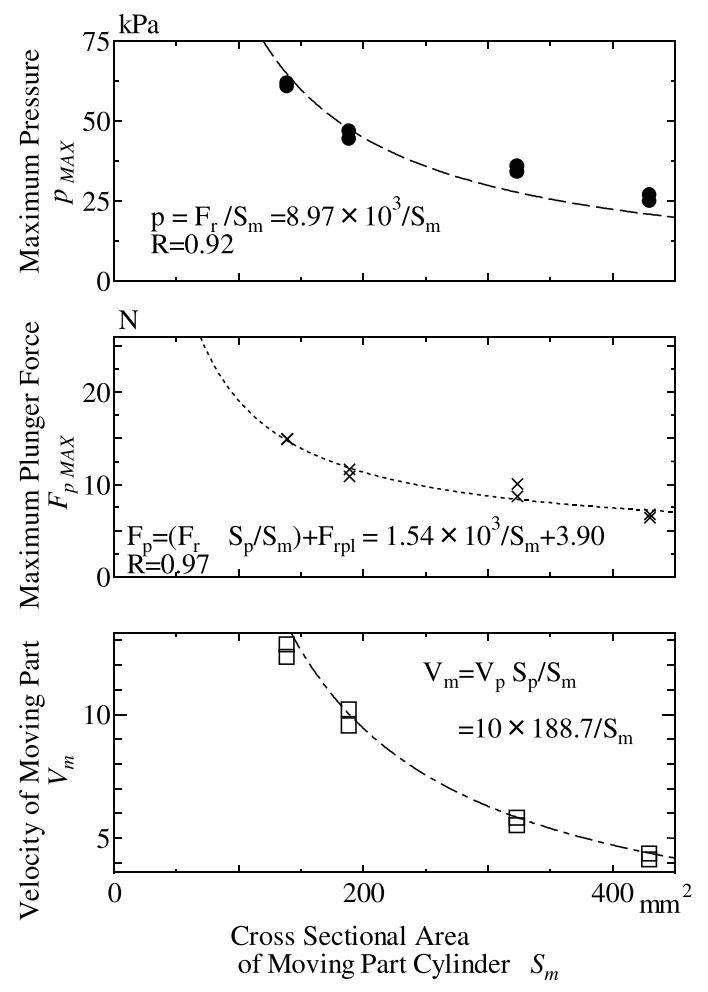

(a) Moving Part Cylinder
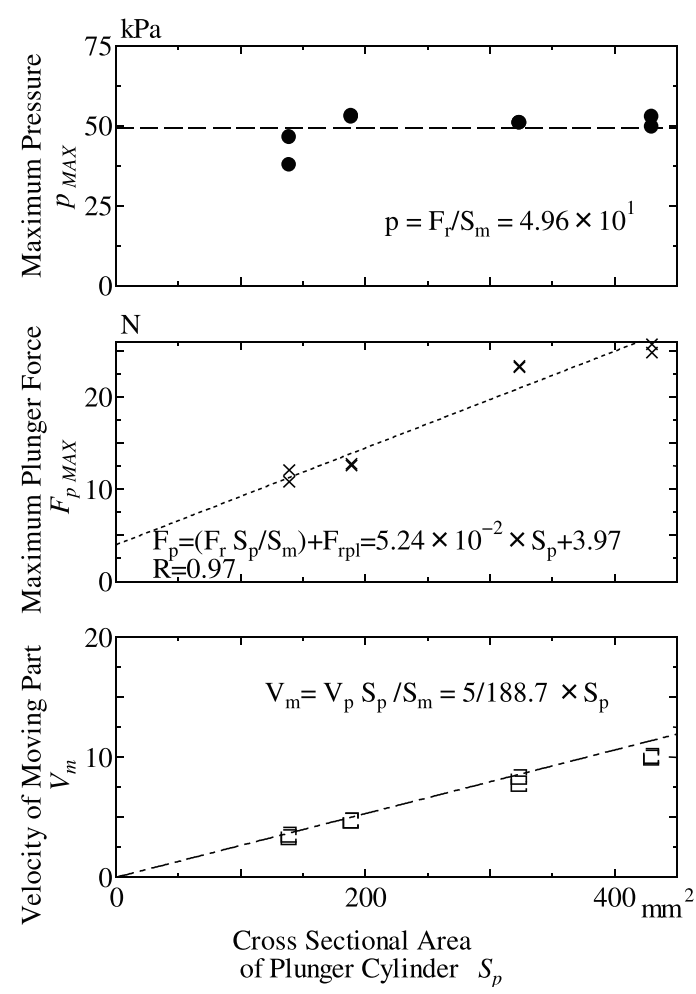

(b) Plunger Cylinder

Fig. 7 Characteristics by Cross Sectional Area of Each Cylinder. 


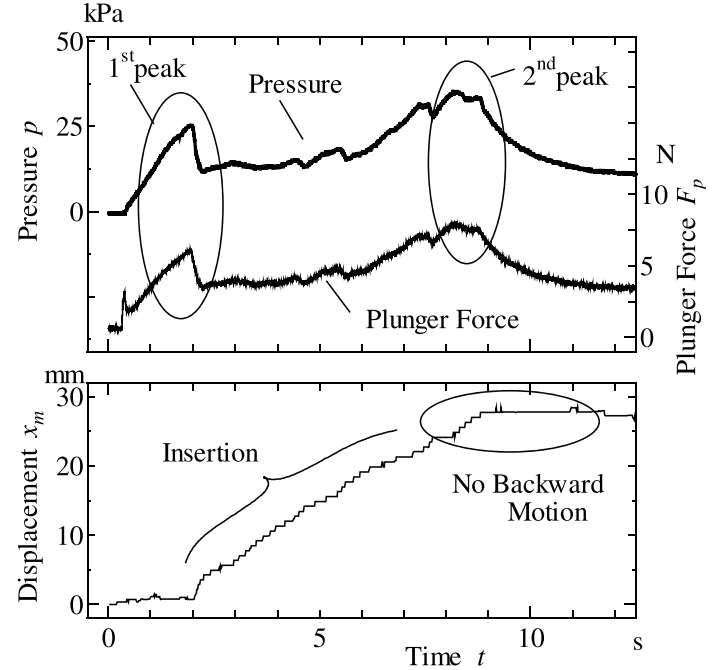

Fig. 8 Time History of Pressure, Plunger Force and Displacement on Insertion to Porcine Tissue.

のシリンジを $\phi 15.5$ の LORシリンジとしたときを基本 として，Fig.7(a)は移動子側シリンジを変えたとき，

Fig. 7(b)はプランジャ側シリンジを変えたときの結果 である。なおプランジャ速度 $V_{p}$ は，用いた測定器の レンジの制限により Fig. 7(a)では 10mm/s， Fig. 7(b)で は $5 \mathrm{~mm} / \mathrm{s}$ とした。 それぞれの条件で繰り返し回数は 2 回とした。

Fig. 7(a)において, Fig. 7(a)上図に穿刺時の圧力 $p$ の 最大值を黒丸で示寸。ここで破線は式(1)を変形した $p=F_{r} / S_{m}$ の式に最小自乗近似をしたものである.こ のとき $F_{r}$ の推定值は $8.97 \mathrm{~N}$ となった. Fig. 7(a)中図に プランジャ操作力 $F_{p}$ を $\times$ 印で示寸.ここで点線は式 （5）の形に最小自乗近似をしたものである。このとき $F_{r} \times S_{p}$ の推定値は $1.54 \times 10^{3} \mathrm{~N} \mathrm{~mm}^{2}, \quad F_{r p l}$ の推定值は 3.90N となった. Fig. 7(a) 下図に移動子が一定速度とな った区間での移動子速度 $V_{m}$ を示す，ここで一点鎖線 は式 (6)より求めた移動子速度の理論值である.

Fig. 7(b)において, Fig. 7(b)上図に穿刺時の圧力 $p$ の 最大值を黒丸で示す.また式(1)に $S_{p}$ が含まれないこ とから，定数として最小近似を行ない破線で示した。 このとき $F_{r} / S_{m}$ の推定值は $4.96 \times 10^{1} \mathrm{~N} \mathrm{~mm}^{2}$ となった. Fig. 7(b)中図にプランジャ操作力 $F_{p}$ を×印で示す.こ こで点線は式(5)の形に最小自乗近似をしたものであ る。このとき， $F_{r} / S_{m}$ の推定值は $5.24 \times 10^{-2} \mathrm{~N} / \mathrm{mm}^{2}$ となり $F_{r p l}$ の推定值は $3.97 \mathrm{~N}$ となった。 Fig. 7(b)下図 に移動子が一定速度となった区間での移動子速度 $V_{m}$

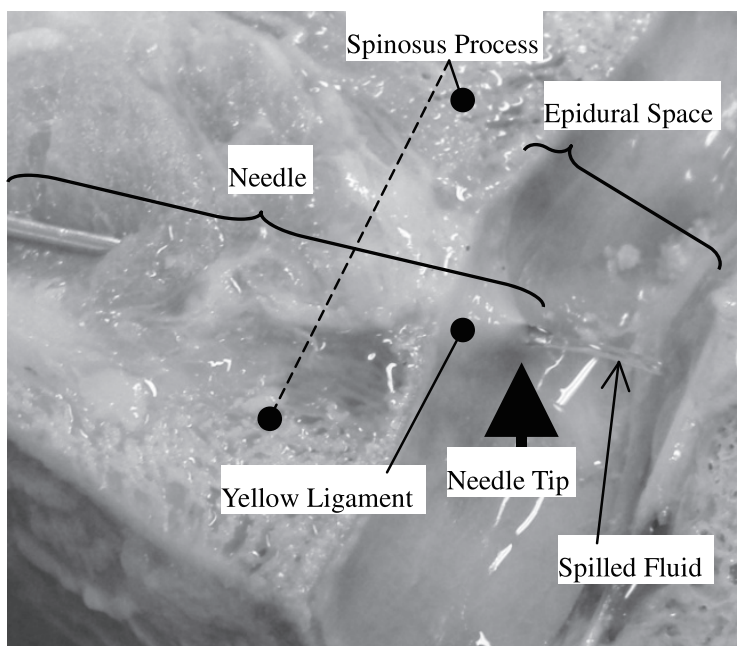

(a) Overall View

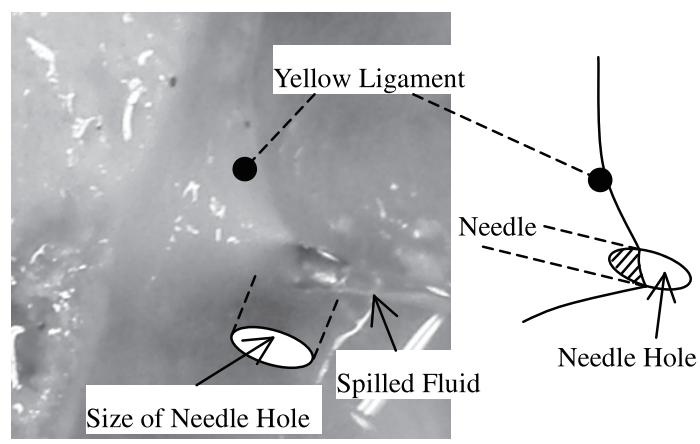

(b) Magnified View of the Needle Tip

Fig. 9 Partial Perforation on the Tip of Needle

を示す。ここで一点鎖線は式 (6)より求めた移動子速 度の理論值である。

\section{2 ブタ骨付きロース肉に対する穿刺結果}

Fig. 8 にブタ骨付きロース肉に対する穿刺を行なっ たときの圧力 $p$, プランジャ操作力 $F_{p}$, 移動子変位 $x_{m}$ を示寸.

Fig. 8 において 8 秒から 9 秒付近で液圧が減少し, 移動子が停止している. 硬膜外穿刺シミュレータに対 して穿刺を行なったときに見られた穿刺後に移動子 が少し戻る現象は発生せず, 針先が硬膜外腔に突き出 した状態で移動子が停止することが確認できた.

移動子が停止した状態で針先を目視確認したとこ ろ, 針穴の断面すべてが硬膜外腔に出ている場合と, 針穴の断面の一部が硬膜外腔に突き出た状態で液体 が抜けて針の進行が停止している場合とがあった.

Fig. 9 に針が一部しか貫通しなかったときの写真とそ 
の模式図を示す. 左から右に向かって針を穿刺した結 果, 黒太矢印の先で針先が硬膜外腔に出て, 針穴から 流体が放出されている. 針の先端に黄色勒帯がテント のように引っ張られており, 実際の針穴の大きさの半 分強が硬膜外腔に露出し, 残りの部分（模式図でハッ チングした部分）は，黄色勒帯の中に隠れている.

なお，この写真は針先の状態を分かりやすく示すた めに Fig. 8 に示した実験とは別に穿刺を行なって撮影 した写真であり, Fig. 8 の実験時よりも穿刺距離が短 く, 針を斜めに刺した状態である.

\section{4. 考察}

まず，シミュレータに穿刺を行ない，液圧を用いて 穿刺が行なえること,および針先が硬膜外腔に到達し て自動的に止まること, が確認できた.

Fig. 6 における最初のピークは移動子が移動し始め る直前に見られることから, ガスケットとシリンダの 間および針とシミュレータの間の静摩擦に起因する と考えられる.

Fig. 6 下図の移動子変位 $x_{m}$ において, 移動子が停止 後に少し戻る現象が発生しているが，これは穿刺パッ ドの筋肉を模したジェルの弾性が大きく, 穿刺中にば ねのように，たわんだ状態になっており，針が硬膜外 腔に貫通して圧力が減少し, 針の穿刺力が減少したこ とによってジェルが戻って針が押し戻されていると 考えられる。

穿刺対象のシミュレータが均一であるため Fig. 7 に おいて 2 回の繰り返しの再現性は高い. 実験值のバラ ツキは, 移動子が異なることによりガスケットとシリ ンダ間の摩擦に違いがあるためであると考えられる。 液室圧力 $p$ は式(1)より, 移動子側シリンジの断面 積 $S_{m}$ に反比例し, プランジャ側シリンジの断面積 $S_{p}$ にはよらないことが予想され, 実験結果もその傾向を 示した. 最小自乗近似で得られた係数から穿刺反力 $F_{r}$ を推定すると, $8.97 \mathrm{~N}, 4.96 \times 10^{1} \times 10^{3} \times(188.7 \times$ $\left.10^{-6}\right)=9.35 \mathrm{~N}$ となった

プランジャ操作力 $F_{p}$ は式(5)より, 移動子側シリン ジの断面積 $S_{m}$ に反比例し，プランジャ側シリンジの 断面積 $S_{p}$ に比例することが予想され, 実験結果もそ の傾向を示した. 最小自乗近似で得られた係数から穿 刺反力 $F_{r}$ を推定すると， $1.54 \times 10^{3} / 188.7=8.16 \mathrm{~N}, 5.24$ $\times 10^{-2} \times 188.7=9.89 \mathrm{~N}$ となり, 液圧の近似曲線から推定 した值とほぼ同じ值となった。
移動子速度 $V_{m}$ は式(6)より, 移動子側シリンジの断 面積 $S_{m}$ に反比例し, プランジャ側シリンジの断面積 $S_{p}$ にはよらないことが予想され, 実験結果と良い一 致を示した.

以上の Fig. 7(a), (b)の結果より, 式(1)から(6)の設計 指針が妥当であることが確認できた.

次に,ブタ組織に対しても穿刺を行なうことができ, 針穴の一部または全部が黄色勒帯を貫通して硬膜外 腔に達した状態で針と移動子が停止することが確認 できた.

針穴の一部だけしか硬膜外腔に達しないことがあ るのは, 針穴の一部だけが黄色勒帯を貫通した時点で 液体が硬膜外腔に放出されてしまい, 液室の圧力が下 がってしまうためであると考えられる. 針穴の一部だ けが硬膜外腔に達しても, 空隙に薬液を注入すること を目的としている場合には問題ない. しかしカテーテ ル挿入を目的としている場合には, カテーテルが通る ように針の進行停止後に針の断面の長さ $1 \mathrm{~mm}$ 程度さ らに針を押しこむなどの手順が必要となると考えら れる.

Fig. 8 では 2 秒付近までに圧力の最初のピークがあ り移動子が変位しない状態があるが, プランジャ側シ リンダと移動子側シリンダの間のエクステンション チューブに混入してしまっていた空気が圧縮されて いる影響と考えられる。

また,ブタ骨付きロース肉に対する実験を行なう中 で, プランジャの速度を速くしすぎると硬膜外腔など の空隙があっても針が停止せず, 一旦止まっても再び 動き出してしまうことがあった. プランジャ速度が小 さいときは問題が起きなかったことから,この現象は 注射針の流路抵抗に起因すると考えられ，さらに検討 が必要である. 現時点では, ゆっくりとプランジャを 動かし，抵抗消失法のようにプランジャ反力が小さく なった，あるいはプランジャが進んでいるにも関わら ず移動子が動かなくなった時点で, プランジャを進ま せることをやめることで対応できると考えられる.

また, 穿刺箇所によっては針先が骨に突き当たって 針の進行が停止し，さらにプランジャを押すことで圧 力が高まりガスケットやコネクタ部から水が漏れて しまう失敗も発生した。骨にあたらない穿刺位置の決 め方などの検討が別途必要である.

以上の実験結果より, 提案したデバイスを用い, プ ランジャを押し込むことで, 穿刺が行なわれ, 針先が 
空隙に達した時点で穿刺が機構的に停止するという 効果, および設計式の妥当性を, 穿刺練習用シミュレ ータおよびブタ骨付きロース肉への穿刺実験によっ て確認することができた。

従来の穿刺デバイスが反力や内圧の変化をセンシ ングして術者に伝えて補助することを目的としてい るのに対して, 本デバイスは, 従来の手技で空隙到達 の判断基準として用いられている内圧の変化を流体 の働きで穿刺力の変化に変換することで, 針先端が空 隙に機構的に停止する新たな機能を実現している.ま た穿刺反力がプランジャを通じて術者にも伝わり，断 面積の設計により穿刺反力を拡大して術者に伝える ことも可能であることから, 術者の感覚を頼りに行な う従来の穿刺を補助することも可能であると考えら れる。

一方, 本デバイスに関して以下のような問題が明ら かになった．まず，プランジャを速く押しすぎると針 が進みすぎてしまうため, プランジャをゆっくりと押 し (本実験では $5 \mathrm{~mm} / \mathrm{s}$ 程度), 反力の低下や移動子の 停止を確認したらプランジャを止めることが必要で ある.また針先が途中で骨などの固い組織にぶつかっ ると圧力が上昇して液漏れなどが発生してしまう. 実 際の硬膜外麻酔用の穿刺では, 針先を骨にあてながら 骨に沿うように針を進ませる手技も行なわれている が，本デバイスを用いるには骨にぶつからないように 穿刺箇所を選んだり，超音波装置などで内部の様子を 見ながら骨を避けて穿刺する等の技術との組み合わ せが必要である．また原理上，目的とする組織の手前 に別の空隙がある場合には，そこで圧力が逃げてしま うため, その部位には使用できない.

\section{5. 結論}

液圧を利用して針を進ませることで機構的に針を 空隙まで穿刺して止めることができる注射器の原理 を提案し，その設計法を明らかにした。本注射器の基 本特性を穿刺練習用シミュレータおよびブタ骨付き ロース肉への穿刺実験によって確認し, 有効性と問題 点とを明らかにした，今後，全身麻酔下のブタを対象 とした in vivo 評価, 人体の穿刺抵抗や筋肉および硬膜 外腔の内圧の值を用いた設計と動作の確認, 本注射器 の硬膜外麻酔用穿刺以外一の適用可能性，などを検討 する予定である。
謝辞: 本研究の遂行にあたり, 独立行政法人科学技 術振興機構の 2008 年度地域ニーズ即応型試験の援助 を受けました。ここに感謝の意を表します。

\section{文献}

1) Boon JM, Abrahams $\mathrm{PH}$, Meiring $\mathrm{JH}$, Welch $\mathrm{T}$, Lumber Puncture. Anatomical Review of a Clinical Skill. Clinical Anatomy 2004;17:544-553.

2）高崎県弓. イラスト麻酔科. 文光堂; 東京, 1994:98-107.

3) Denis T, King-Wei H, Allaudin AK, Victoria AL, Robert NR. Instrumentation of the Loss-of-Resistance Technique for Epidural Needle Insertion. IEEE Trans on Biomedical Engineering 2009;56(3):820-827.

4) Timo J. Lechner, Maarten G. van Wijk, Ad J. Maas, Frank R. van Dorsten, Ronald A. Drost, Chris J. Langenberg, Leo J.Teunissen, Paul H. Cornelissen, Jan van Niekerk, Clinical Results with the Acoustic Puncture Assist Device, a New Acoustic Device to Identify the Epidural Space. International Anesthesia Research Society 2003;96:1183-1187.

5) 特開 2004-313672, 麻酔針及びその穿刺クリック感検出 装置.

6) 特許 4164730, 選択分離膜. 